\title{
Calendar Anomalies or illusions? Evidence from Pakistan Stock Market
}

\author{
Jahanzaib ALVi ${ }^{1}$, Muhammad REHAN², Ismat MOHIUDDIN ${ }^{3} \odot$
}

\begin{abstract}
The stock market is the reflection of any country's economy around the globe, the purpose of the study was to figure out the anatomies of anomalies in the calendar, Year Turn Effect keeping the first month as Jan-Jul and last month as Jun-Dec, Month Turn Effect (First and Last Week of the month) and Week Turn Effect (First and Last day of the week) covering period for KSE-100 and KSE All shares from Jan-2001 to Jun-2019 and rest three indices were taken from inception date, EGARCH model was selected based on prescribed criterion $\mathrm{AIC}, \mathrm{SIC}$, and $\mathrm{HQC}$ test, and last results were retest with stock market sensitivity to key macroeconomic factors such as Interest Rate (KIBOR), Treasury Bills Rates, and Exchange Rate. Findings revealed a strong clustering feature impact on conditional variance on Year Turn, Month Turn, and Week Turn Effect with mixed of market returns. The research suggested four considerable factors (1) Events, (2) Role of Information, (3) Market Timing and (4) Sovereign Variable affection on market, further it also suggested for future research to stretch data set and employ the bootstrapping method and different statistical techniques for rigorous results.
\end{abstract}

Keywords: Word; Calendar anomalies, Month-of-the-Year-turn-effect, Week-of-the-Month-turn-effect, Day-of-the-Weekturn-effect, Market Volatility

JEL: G10, G14, G41, L19, E44

\section{Introduction}

In the non-investing world, an irregularity is an abnormal or rare incidence. In commercial markets, variances denote to conditions when security or group of securities achieves different from the opinion of the competitive market place, where the prices of stocks are supposed to reveal all accessible data consistently. With the continuous publicize and quick dispersal of the latest evidence, sometimes it is difficult to accomplish efficient markets and even more tough to sustain. There is market deviation; some of them occur once \& disappear. Whereas others are constantly detected. So, in this section, we have viewed at some very common repetitive variances and have studied whether any challenge to make the most of them can be valuable. A calendar impact is any market irregularity or economic impact which seems to be associated with the calendar. Such impacts comprise the various practices of securities exchanges based on some days of the week some time intervals in the month \& a year as well.
Stock markets in Pakistan's capacity also have a certain result and construct an expected figure in supports of unproductive markets. In this circumstance, by evaluating market return and transaction facts \& figures volume of Pakistan Stock Exchange (PSX), this analysis tries to explore the relationship between Ramadan \& return of market instability and trade capacity. The purpose of the study prepared reviews of different works of literature in the second portion; procedure and outcomes in the third and fourth sections, separately; and conclude the results in the fifth section.

The Efficient Market Hypothesis (EMH) says that productively of the market procedure and shows the effect of all accessible data; consequently, no financial special investor can make irregular returns. Still, as observed through the analysis of existing studies, different variations like Month of the Year Effect, Day of the Week Effect, Holiday Effect, and so forth have been found in the Pakistan stock exchange. The existence of 
such irregularity empowers financial specialists to plan and make irregular benefits. In this manner, looking at the presence of variation would assist financial specialists with making procedures Before Invest in Stocks. An efficient market can immediately process the data which would be indicating security prices. The Information Transmission Mechanism Certifies that the stock returns over the entire days, months are equivalent, and the Market Applicant, and the Rational Financial Decision Maker, can't gain additional incomes. It is to be noticed that the profits establish just a single portion of the decision-making method. An additional portion of decision making is the Evaluation of threat or instability of profits. It is critical to take note that there are changes in the Instability of Stock Yields constantly Days of-the Week, Months of the Year, and Days of the Month. Few of the past researches have concentrated on Month of the Year Effect. The researches have rotated around the chance of Tax Loss Selling assumption in West.

To inquire about the presence of calendar anomalies in the returns and volatility of the selected indices during the YearTurn, Month Turn, and WeekTurn Effect. However, studies have been conducted on week turn effect and year turn effect, therefore measuring week turn effect gives streamline to escalate year turn effect, this piece of research will be covering the gap by studying the month and year turn effect specifically in Nigerian Stock Market. The crux of the study is to examine the empirical findings in the Nigerian Stock Market which is considered as the first Stock Market in West Africa and the biggest one in the whole region. The methodology employed is the Stochastic Dominance (SD) approach. SD approach has been widely used as seen in Borges Brooks, R. M., \& Kim, H. (1997)., and Gasbarro, Wong, \& Zumwalt, Canova, F., \& Hansen, B. E. (1995).

\section{Literature Review}

In the financial literature, there are several discussions about market anomalies which can affect the performance of the stock market efficiency.

\section{Day of the week effect:}

Many types of research have been conducted to identify the day of the week effect in the stock market:

\section{Settlement period:}

It is arguments in the financial literature that the high return on pay in the day while the low return payout day, most of the research reject this theory because every stock has different settlement days and date. There is 6-15 days settlement period in the UK while in Hong Kong only one day settlement period (Agrawal, A., \& Tandon, K. 1994).

\section{Trading/calendartime:}

It is recognized that the market return should be more than 3 times on the Monday than other weekdays as the market is close on Friday and open on Monday that's why Monday return should be more than 3 times, but many types of research has been conducted on that topic and found market negative on Monday. Chang, Eric C., J. Michael Pinegar, and Ravi Ravichandran (1993) researched the weekly market effect they found that the stock market of the USA has the lowest return or negative return on Monday. Rogalski, Richard J. (1984) conducted the research and results reveal that the market returns are negative on every Monday.

\section{Retail investor trading:}

Some researchers have been conducted on small and large size of firms which show that the small firm more trade in the stock than large firms on Monday.

\section{Week-end effect Review of Literature:}

The weekend impact comprises of an adverse end of the week return, suggesting that the returns on Friday are higher than the profits on the next Monday. These schedule variations have been broadly concentrated in the financial Studies by researchers, for example, French, K. R. (1980), Gibbons and Hess (1981), Jaffe, J., \& Westerfield, R. (1985), Pettengill, G. N. (2003), or Cross, F. (1973). Examine the 'Friday impact' related to the expiry day impact because the stock index forecasts and choices Expiry days normally decrease on the third Friday of the Expiry months, and the two impacts are related to expanded exchanging volume. Furthermore encouraging the Tuesday impact in the Japanese financial exchange, furthermore reported essentially positive profits for Wednesdays, and the week after week models were seen as increasingly articulated for little firms. Additionally opposed that the day-of-theweek impact was clear just when the earlier week's returns were decreasing, then again, Doyle and Chen (2009) opposed that the day-of-the-week impact was not fixed, however roving, and relied upon the most recent week's profits. Even though Hui (2005) and Kohers, G., Kohers, N., Pandey, V., \& Kohers, T. (2004) didn't discover proof of the day-of-the-week impact in Japan, Doyle and Chen (2009) determine that the impact didn't normally become extinct. 


\section{The month of the year effect:}

Many types of research have been conducted to identify the month of the year effect in the stock market:

\section{Taxloss selling:}

It has been concluded by the Branch, B. (1977) and Johnston, K., \& Cox, D. R. (1996) that the firm's stock which not performed well in the half-yearly usually they give profit and increase in the January of the coming year. Further researchers i.e. Lee, K. Y., \& Chang, C. S. in 1988, Lee, I. in 1992, and Athanassakos, G. in 1997 found that returns of January are positive.

\section{Turn-of-the-month review of the literature:}

One more predictable impact is the turn-of-themonth impact or end-of-month impact, involving further analogous impacts, for example, the intra-month, the Weeks-of-the-month, and the month to month impacts. The intra-month impact comprises optimistic returns in the first week of the month (Ariel 1987; Rosenberg 2004). The turn-of-the-month impact studied by Cadsby and Ratner in 1992 and they found regularly considered as the securities flow of prices on the most recent days of a month and three initial days of the following month. The four-day turn-of-month time frame expresses to $87 \%$ of the normal month to month return (Kunkel, Compton, \& Beyer, 2003). A reasonable Clarification is the adjustment of repayments at the turn of the month (Ogden 1990). Examining carefully traded finnish stocks, Nikkinen, J., Sahlström, P., Takko, K., \& Äijö, J. (2009) become aware of the publication of major US macroeconomic news is powerful the turnof-the-month and intra-month irregularities. Also, the more significant profits at the turn-of-the-month are related to flow in exchanging volume, which is possibly affected by the purchasing pressure toward the month's end (Booth, G. G., Kallunki, J. P., \& Martikainen, T. 2001). Dynamic effects on the volume of shares are found trading in the last seven day stretch of the month the ending stock index futures, options, and money markets Martikainen, Teppo, Jukka Perttunen, and Vesa Puttonen (1995). The exact proof from the study extensively strengthens the positive connection in the middle of capacity and worth changes (Harris and Raviv 1993; Hong and Stein 2007). The Researches on the price-volume of stock connection revealed two types of price indicators that are associated with exchanging volume, first the extent (or total valuation) of the value change, for example, Operation (Assogbavi and Osagie 2006); secondly, the value variation essentially (or the Basic-worth \& variation in value), (Karpoff 1987). The va- lue modification can be either the log-value differences or the proportion of price variation.

\section{Calendar effects Review of literature:}

Most of the Studies on calendar impacts take an aspect at the association between schedule irregularities and value returns, while the connection with the exchanging the number of shares is hardly secured. We initiate through measuring the important schedule impacts and afterward, we figure out the exact results on the association among volume and cost, to conclude the schedule impacts and their effect on exchange volume.

Dhankar, R. S. (2019) studied calendar anomalies by making classification buckets such as Week Turn Effect, Month Turn Effect, Year Turn Effect and Month Turn Effect separately, author targeted five of the south Asian Stock Markets, and findings revealed that in the class of Week Turn Effect clustering features impact is found in the Sri Lankan and Bangladeshi Stock Market, there is mixed of relationships such as positive and negative association with Tuesday and Friday returns respectively but this is more than zero for Sri Lanka, but in Bangladesh, the returns on Monday are significantly negative and that on Thursday and Saturday are significantly positive.

Calendar impacts are irregularities in the money related markets have a relation with schedule regularity. The Studies on schedule impacts (In general on behavioral finance) are intensely argumentative and its experimental conclusions are normally uncertain. One reason is that each schedule impact is normally examined in exclusion, although an entire world of schedule impacts would decrease the impact extent of the schedule variations Sullivan, R., Timmermann, A., \& White, H. (2001). It is value declaring that the calendar impacts have constantly been distinguished ex-present due to their reliance on practical evidence ancient time sequence supportive their Survival. The elements of some schedule impacts are additionally recognized to deviations or opposite after some time (Dimson and Marsh 1999; Schwert, G. W. (2003); P. R., Lunde, A., \& Nason, J. M. (2005).

\section{Research Methodology}

Research Method states to technique is being used to perform research related to business; it offers a technique to examined outcome for particular Challenge in Research Study intended for the whole study is conducting, it shows the path, road-map, combination, 
and sense for creating dependable results and create outcome beneficial for every stake-holders used for that study, a proper method can Create comprehensive outcomes or vice versa, that's why procedure retains the worth of core part in researches.

Pakistan's Stock trade is one of the several unique powerful of Asia. To investigate if the, turn year, turn Month, and turn week impact are available in the Pakistan Stock market, the accompanying five indices have been chosen remembering the different gatherings of stocks recorded in PSX.
1. KMI All Share
2. KMI 30
3. KSE All Share
4. KSE 30
5. KSE-100

The Philosophy of this examination is focusing on the constructive side because the research dependent on the study relates to natural phenomena and the complete data about this investigation was driven from genuine explanation and rationales. This examination is optional research and deductive methodology is applied to explain the outcome of this report, subsequently, several types of research have been focused on similar factors as utilized right now, which is the reason this study approach thinks of secondary research approach structure which is deductive. As this is a secondary type of research, the information is gathered by reported information from various sources where documented information is accessible moreover Pakistan Stock Exchange, Investing.co and Yahoo Finance

\section{Sample and Sampling Method:}

This study is ultimately optional research; several studies have been directed on the someway equivalent

\section{Symbolically Representation of Hypothesis}

\section{Equation \# 1 (For Year Turn Effect)}

$H_{0}: \beta_{1,7=} \beta_{2}=\beta_{3}=\beta_{4}=\beta_{5}=\beta_{6}=\beta_{8}=\beta_{9}=\beta_{10}=\beta_{11}=\beta_{12}$

$H_{1}: \beta_{1,7} \neq \beta_{2}=\beta_{3}=\beta_{4}=\beta_{5}=\beta_{6}=\beta_{8}=\beta_{9}=\beta_{10}=\beta_{11}=\beta_{12}$

( 1 is January and 7 is July)

\section{Equation \# 2 (For Month Turn Effect)}

$$
\begin{aligned}
& H_{0}: \beta_{f, 1}=\beta_{1}=\beta_{2}=\beta_{3}=\beta_{4}=\beta_{5}=\beta_{6}=\beta_{7}=\ldots \ldots \ldots \ldots \ldots \ldots=\beta_{29=} \beta_{30} \beta_{31} \\
& H_{0}: \beta_{f, l} \neq \beta_{1}=\beta_{2}=\beta_{3}=\beta_{4}=\beta_{5}=\beta_{6}=\beta_{7}=\ldots \ldots \ldots \ldots \ldots \ldots . . . \ldots \beta_{29=} \beta_{30=} \beta_{31}
\end{aligned}
$$

(f is first day of month and $i$ is last day of the month) point yet its various zones, distinctive time prospects, and with the diverse theme. Though the necessary information is just reachable on the real information base sources such like Pakistan Stock Exchange, so information of all indices recorded as KSE-100 file from "May 25, 1994, to June 28, 2019", KSE All Shares file from "October 17, 2005, to June 28, 2019", KMI All Shares index "May 10, 2016, to June 28, 2019", KSE-30 index "July 31, 2006, to June 27, 2019", and KMI All Share Index from "September 03, 2008, to June 28, 2019, since mostly indices generated in future \& comprise a large portion of the index later its initiation. Initiation date of every index in unambiguously declared in the overview portion. Equivalent Probability Sampling Method (EPSM) is utilized to gather date from accessible and useful assets.

\section{Variables:}

\section{Independent and Dummy Variables:}

(1) Year Turn Effect, (2) Month Turn Effect, (3) and Week Turn Effect

\section{Dependent Variables:}

Returns of (1) KMI All shares, (2) KMI 30, (3) KSE All Share, (4) KSE-30, and (5) KSE-100 index.

\section{Hypothesis:}

Null Hypothesis. There is no presence of calendar anomalies in the returns and volatility of the selected indices during Year Turn, Month Turn, and Week Turn Effect.

Alternative Hypothesis. There is the presence of calendar anomalies in the returns and volatility of the selected indices during Year Turn, Month Turn, and Week Turn Effect. 
Equation \# 3 (For Week Turn Effect)

$H_{0}: \beta_{f w, w}=\beta_{1}=\beta_{2}=\beta_{3}=\beta_{4}=\beta_{5}$

$H_{0}: \beta_{\text {fw, } / w} \neq \beta_{2}=\beta_{3}=\beta_{4}$

(fw is the first day of the week and I $w$ is the last day of the week)

\section{Results and Discussion}

Table 4: Descriptive Statistics of Returns of Selected Indices

\begin{tabular}{llllll}
\hline & KSE ALL SHARE & KSE-100 & KSE-30 & KMI-30 & KMI ALL SHARES \\
\hline Mean & $0.15 \%$ & $0.15 \%$ & $0.02 \%$ & $0.07 \%$ & $8.02 \mathrm{E}-05$ \\
\hline Median & $0.10 \%$ & $0.10 \%$ & $7.37 \mathrm{E}-05$ & $0.02 \%$ & $0.01 \%$ \\
\hline Std. Dev. & $4.37 \%$ & $4.40 \%$ & $1.31 \%$ & $1.18 \%$ & $0.98 \%$ \\
\hline Skewness & 14 & 14 & 0 & 0 & 0 \\
\hline Kurtosis & 405 & 396 & 6 & 6 & 5 \\
\hline Jarque Bera (Prob.) & 30797896 & 29437720 & 1602 & 1030 & 148 \\
\hline Probability & 0.00 & 0.00 & 0.00 & 0.00 & 0.00 \\
\hline
\end{tabular}

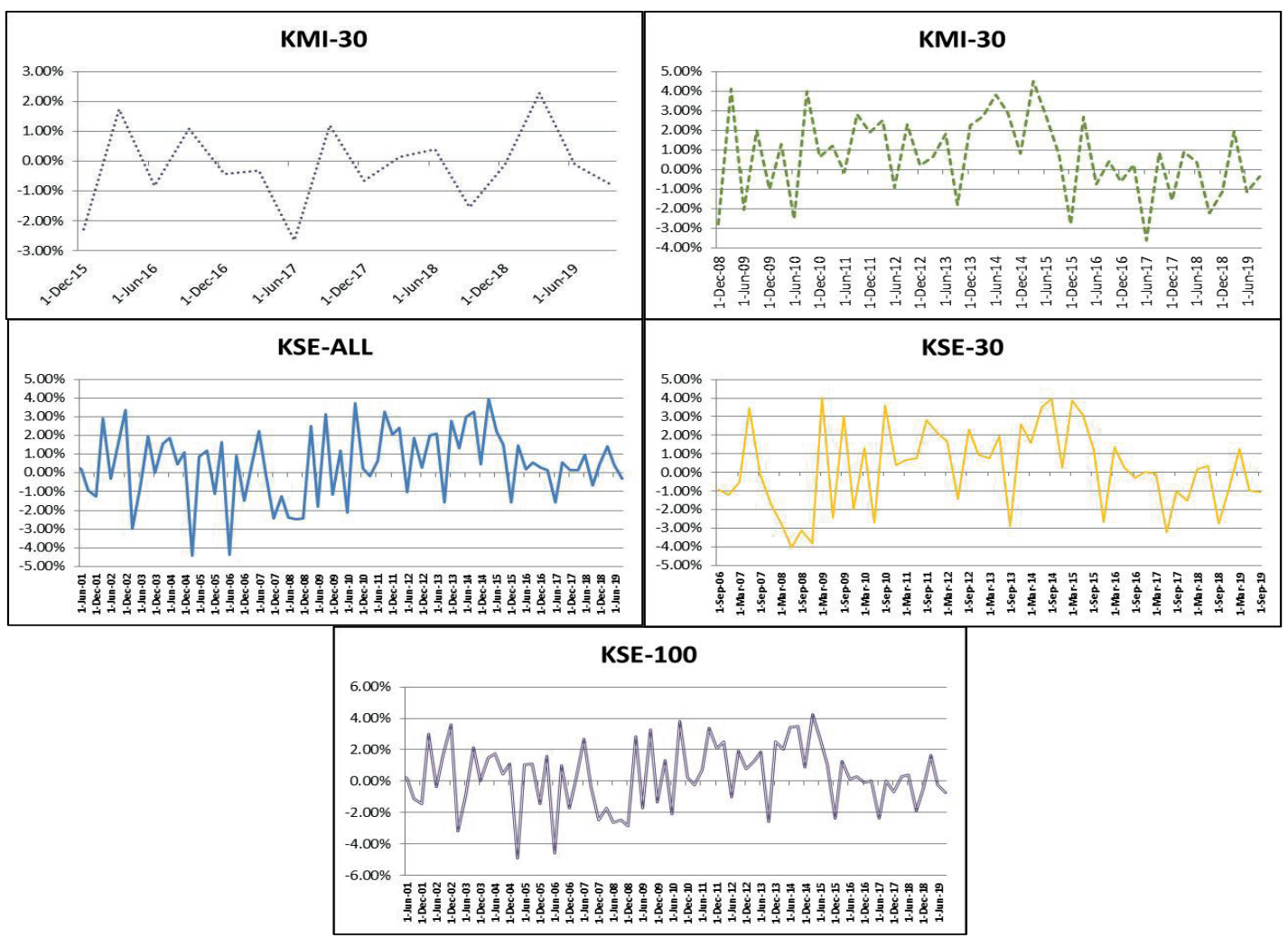

KSE-100 returns found the most volatile segment recorded $4.40 \%$ standard deviation compare to KSE All returns $4.37 \%$ standard deviation but the least volatile indices as KMI All Returns (Stdv:0.98\%), KMI-30 returns (STDV:1.31\%) and KSE-30 returns (Stdv:1.31\%) respectively, further graphical representation showcasing the same results in the context of the volatility of stock indices. Moving forward, considering only volatility would not be viable, hence above illustration witnesses significant fact that higher risk bearing indices having higher return and vice versa, comparing median of indices KSE-100 and KMI All returns are quite similar (10\% 
$\& 10 \%)$ respectively, but the least return producing indices is KSE-30 index returns rest of the KMI-30 and KMI All Share returns are $0.023 \%$ and $0.013 \%$ respectively based on average return (Median). Stats defines the structure of the population as Skewness showcased that data of KSE-100 and KSE All indices are right-tailed (signed + ) and the rest of them are left (signed -) tailed, further Leptokurtic or Kurtosis values in between 4.95 and 404.55 .

Unit Root in data set can ruin entire results which may lead to such spurious findings (Dickey \& Fuller, 1979), to revoke this massive problem Test Augmented Dickey-Fuller was employed, as mentioned above, All of the variables are stationary on the level, as $p$-value is less than 0.05 or $5 \%$ which indicates that data is stationary and ready for further modeling.

Table 5: ADF-UNIT Root Test for Selected Indices (AT LEVEL)

\begin{tabular}{lll}
\hline Indices & t-Statis & Prob. Value \\
\hline KSE ALL SHARE & -15.27 & 0.00 \\
\hline KSE-100 & -15.33 & 0.00 \\
\hline KSE-30 & -46.75 & 0.00 \\
\hline KMI-30 & -43.73 & 0.00 \\
\hline KMI ALL SHARES & -25.78 & 0.00 \\
\hline
\end{tabular}

Table 6: Year Turn Effects in Stock Market

\begin{tabular}{|c|c|c|c|c|c|c|c|c|c|}
\hline \multicolumn{10}{|l|}{ EGARCH MODEL } \\
\hline & \multicolumn{3}{|c|}{ KSE All Shares } & \multicolumn{3}{|l|}{ KSE-100 } & \multicolumn{3}{|l|}{ KSE-30 } \\
\hline & Coeff. & z-stat. & Prob. & Coeff. & z-stat. & Prob. & Coeff. & z-stat. & Prob. \\
\hline \multicolumn{10}{|l|}{ Mean Equation } \\
\hline C & 0.001741 & 23.20346 & 0 & $2.63 \mathrm{E}-03$ & 22.19814 & 0 & $-1.12 \mathrm{E}-10$ & -0.000000695 & 1 \\
\hline First Month of the Year - Jan & 0.000175 & 0.727153 & 0.4671 & -0.007761 & -12.07403 & 0 & 0.001576 & 2.56725 & 0.0103 \\
\hline First Month of the Year - July & -0.001332 & -9.170196 & 0 & -0.068425 & -115.08 & 0 & 0.001502 & 3.013223 & 0.0026 \\
\hline Last Month of the Year - Jun & 0.010149 & 158.819 & 0 & $1.37 \mathrm{E}-02$ & 85.04246 & 0 & 0.0000459 & 0.074142 & 0.9409 \\
\hline Last Month of the Year - Dec & 0.001604 & 10.41871 & 0 & 0.000493 & 3.086242 & 0.002 & 0.003381 & 13.41385 & 0 \\
\hline $\mathrm{AR}(1)$ & 0.249693 & 17.41088 & 0 & 0.24988 & 17.42476 & 0 & 0.360328 & 21.85784 & 0 \\
\hline \multicolumn{10}{|l|}{ Variance Equation } \\
\hline C & -1.056201 & -92.08056 & 0 & -1.044658 & -62.7223 & 0 & -0.795331 & -15.82518 & 0 \\
\hline ARCH Term & 1.31318 & 116.2874 & 0 & 1.371174 & 91.45481 & 0 & 0.351593 & 17.03868 & 0 \\
\hline Asymmetry term & -0.677631 & -144.0163 & 0 & -0.57264 & -59.66831 & 0 & -0.133527 & -13.19517 & 0 \\
\hline GARCH & 0.956722 & 899.1177 & 0 & 0.96385 & 583.9554 & 0 & 0.941149 & 195.4803 & 0 \\
\hline \multicolumn{10}{|l|}{ ARCH LM Test } \\
\hline & & t-Statistic & Prob. & & t-Statistic & Prob. & & t-Statistic & Prob. \\
\hline & & -0.140125 & 0.8886 & & -0.175279 & 0.8609 & & -1.004934 & 0.315 \\
\hline & KMI-30 & & & KMI All Sh & Iares & & & & \\
\hline & Coeff. & z-stat. & Prob. & Coeff. & z-stat. & Prob. & & & \\
\hline \multicolumn{10}{|l|}{ Mean Equation } \\
\hline C & $5.25 \mathrm{E}-11$ & $6.01 \mathrm{E}-07$ & $1.00 \mathrm{E}+00$ & 0.000164 & 0.536194 & 0.5918 & & & \\
\hline First Month of the Year - Jan & 0.001155 & 1.868357 & 0.0617 & 0.001676 & 2.256016 & 0.0241 & & & \\
\hline First Month of the Year - July & 0.002038 & 3.833429 & 0.0001 & 0.000445 & 0.352853 & 0.7242 & & & \\
\hline Last Month of the Year - Jun & 0.000512 & 0.917357 & 0.359 & 0.000168 & 0.209938 & 0.8337 & & & \\
\hline Last Month of the Year - Dec & 0.004 & 21.9213 & 0 & 0.000873 & 1.02361 & 0.306 & & & \\
\hline $\operatorname{AR}(1)$ & 0.323047 & 17.65822 & 0 & 0.099266 & 3.011284 & 0.0027 & & & \\
\hline \multicolumn{10}{|l|}{ Variance Equation } \\
\hline C & -0.766437 & -12.47259 & 0 & -0.727134 & -6.202128 & 0 & & & \\
\hline ARCH Term & 0.343669 & 15.43712 & 0 & 0.160394 & 4.729869 & 0 & & & \\
\hline Asymmetry term & -0.155843 & -12.72491 & 0 & -0.15476 & -7.330061 & 0 & & & \\
\hline GARCH & 0.943919 & 156.8359 & 0 & 0.936382 & 82.88029 & 0 & & & \\
\hline \multicolumn{10}{|l|}{ ARCH LM Test } \\
\hline & & t-Statistic & Prob. & & t-Statistic & Prob. & & & \\
\hline & & -0.44757 & 0.6545 & & 0.065011 & 0.9482 & & & \\
\hline
\end{tabular}


In this segment Year, Turn Effect was encountered to build an understanding of market anomalies in the month when the firm closes its account further the month after account closed, hence below are few classifications that witnessed sum of percentage for account ending the month in the market.

Around $70 \%$ of firms' account end month is June, so above mentioned estimated EGARCH model resulted as AR (1) heteroscedasticity test was employed for each index and that found significant at 0.05 . ARCH term, $\mathrm{GARCH}$ term, and Asymmetry term were significant at 0.05 in the equation, for KSE-All shares January found with no such market anomalies but Month of July found negative clustering effect and rest of the two months June and December resulted in clustering effect as a positive trend, further going forward it is crystal clear that in year turn effect end of the month reported significant positive turn effect due to the disclosure of financial statements and dividend announcement as above information table shown, but beginning month reports negative clustering effect on conditional variance.

In KSE-100 index clustering effect was detected as negative it the beginning month of the accounting year and positive in ending month of the accounting years, this what because of dividend announcement and rest of the technical and fundamental variables, findings revealed that firm classified in KSE-30 index exhibited positive clustering effect in each of these periods, meaning investor who tends to earn the only dividend that but when it's time for dividend earnings and sales dramatically after receiving dividend which creates positive clustering effect (Market Anomalies) in conditional variance, further these results are same as $\mathrm{KMI}-30$ index because it encompasses more than $70 \%$ similar companies in both index, further the chunk is the month of June did not explore any abnormal return, and finally KMI All Shares detected market anomalies only in January. ARCH-LM test was employed that is not significant at 0.05 , meanings there are no residuals of EGARCH do not have the ARCH type of heteroscedasticity and the model is fit for explain findings.
$A R(1)$ heteroscedasticity test was employed for each index and that found significant at 0.05 . ARCH term, GARCH term, and Asymmetry term were significant at 0.05 in the equation, therefore in KSE-ALL and KSE100 represented that first and last week of the month exhibited negative returns or in other words negative clustering effect on conditional variance, which perhaps suggesting that last week is for the salary week for salaried class investors and expenditure closing week for businessman so it seems investment is stock indices such KSE-100 and KSE All share goes down in both of the weeks to due to natural expenses of an individual and corporates, that what suggested us exploit market anomalies by beating volatility, KMI All resulted as market anomalies were detected in the only first week of the month but not in the last week of the month. Hence it has been diagnosed that there are calendar year anomalies in each the first and last week of each month of the year. ARCH-LM test was employed that is not significant at 0.05 , meanings there are no residuals of EGARCH do not have ARCH type of heteroscedasticity and the model is fit for explain findings.

In the above equation AR (1) heteroscedasticity test was employed for each index and that found significant at 0.05 . ARCH term, GARCH term, and Asymmetry term were significant at 0.05 in the equation, in KSE-All Index which exhibited positive returns in each of first day and last day of the week, hence KSE-100, KSE-30 and KMI-30 indexes reported negative return in the first day of the week and positive return in last day of the week, that witnessed investor uncomfortable in the start of the week while they are quite confident on the last day of the week and make the most of their investment by trading. Whereas KMI All index shows that in the first week the results are similar to other indices but on the last day of the week there no change with KMI All Shares index. ARCH-LM test was employed that is not significant at 0.05 , meanings there are no residuals of EGARCH do not have ARCH type of heteroscedasticity and the model is fit for explain findings.

\begin{tabular}{lllll}
\hline Year Ending & \# of Companies & $\mathbf{\%}$ & Total Volumes (Par Value) in Million & Total Volumes (Market Value) in Million \\
\hline Dec & $\mathbf{1 0 0}$ & $\mathbf{2 2 . 3 \%}$ & $702,607.85$ & $3,061,064.37$ \\
Mar & $\mathbf{4}$ & $\mathbf{0 . 9 \%}$ & $2,870.57$ & $71,167.95$ \\
Jun & $\mathbf{3 1 5}$ & $\mathbf{7 0 . 2 \%}$ & $626,748.17$ & $2,440,548.65$ \\
Sep & $\mathbf{2 9}$ & $\mathbf{6 . 5 \%}$ & $10,999.59$ & $80,883.66$ \\
Nov & $\mathbf{1}$ & $\mathbf{0 . 2} \%$ & 142.16 & $1,051.42$ \\
\hline Total & 449 & & $1,343,368$ & $5,654,716$ \\
\hline
\end{tabular}


Table 7: Month Turn Effects in Stock Market

\section{EGARCH MODEL}

\begin{tabular}{|c|c|c|c|c|c|c|c|c|c|}
\hline & \multicolumn{3}{|c|}{ KSE All Shares } & \multicolumn{3}{|l|}{ KSE-100 } & \multicolumn{3}{|l|}{ KSE-30 } \\
\hline & Coeff. & z-stat. & Prob. & Coeff. & z-stat. & Prob. & Coeff. & z-stat. & Prob. \\
\hline \multicolumn{10}{|l|}{ Mean Equation } \\
\hline C & 0.005113 & 77.72053 & 0 & 0.004137 & $5.57 \mathrm{E}+01$ & 0 & -0.000268 & -1.125772 & 0.2603 \\
\hline First Week of the Month & -0.004562 & -41.66584 & 0 & -0.002814 & -15.13802 & 0 & 0.003025 & 9.864402 & 0 \\
\hline Last Week of the Month & -0.005812 & -26.17382 & 0 & -0.004867 & -24.1514 & 0 & 0.000749 & 1.977709 & 0.048 \\
\hline $\mathrm{AR}(1)$ & 0.249133 & 17.36922 & 0 & 0.249417 & 17.39032 & 0 & 0.364355 & 22.13917 & 0 \\
\hline \multicolumn{10}{|l|}{ Variance Equation } \\
\hline C & -1.038867 & -70.80853 & 0 & -1.129356 & -68.97347 & 0 & -0.849262 & -15.70626 & 0 \\
\hline ARCH Term & 1.197085 & 106.2347 & 0 & 1.273905 & 97.05457 & 0 & 0.319505 & 14.71033 & 0 \\
\hline Asymmetry term & -0.714174 & -139.341 & 0 & -0.730612 & -140.7506 & 0 & -0.129153 & -11.91479 & 0 \\
\hline GARCH & 0.947077 & 580.4589 & 0 & 0.941907 & 526.799 & 0 & 0.93276 & 178.0904 & 0 \\
\hline
\end{tabular}

ARCH LM Test

\begin{tabular}{|c|c|c|c|c|c|c|c|c|}
\hline & & t-Statistic & Prob. & & t-Statistic & Prob. & t-Statistic & Prob. \\
\hline & & -0.087521 & 0.9303 & & -0.096886 & 0.9228 & -0.645954 & 0.5184 \\
\hline & \multicolumn{3}{|l|}{ KMI-30 } & \multicolumn{3}{|c|}{ KMI All Shares } & & \\
\hline & Coeff. & z-stat. & Prob. & Coeff. & z-stat. & Prob. & & \\
\hline \multicolumn{9}{|l|}{ Mean Equation } \\
\hline C & $-3.86 \mathrm{E}-05$ & -0.167861 & 0.8667 & -0.000136 & -0.375834 & 0.707 & & \\
\hline First Week of the Month & 0.003465 & 12.43205 & 0 & 0.002073 & 3.547415 & 0.0004 & & \\
\hline Last Week of the Month & 0.000822 & 2.283766 & 0.0224 & 0.000582 & 0.947631 & 0.3433 & & \\
\hline AR (1) & 0.333475 & 18.29825 & 0 & 0.107264 & 3.256544 & 0.0012 & & \\
\hline \multicolumn{9}{|l|}{ Variance Equation } \\
\hline C & -0.823865 & -12.73473 & 0 & -0.727699 & -6.327799 & 0 & & \\
\hline ARCH Term & 0.287545 & 13.18501 & 0 & 0.168226 & 5.206523 & 0 & & \\
\hline Asymmetry term & -0.148335 & -12.53878 & 0 & -0.144081 & -6.477274 & 0 & & \\
\hline GARCH & 0.934015 & 151.36 & 0 & 0.937015 & 84.11416 & 0 & & \\
\hline \multicolumn{9}{|l|}{ ARCH LM Test } \\
\hline & & t-Statistic & Prob. & & t-Statistic & Prob. & & \\
\hline & & 0.339098 & 0.7346 & & 0.008924 & 0.9929 & & \\
\hline
\end{tabular}


Table 8: Week Turn Effects in Stock Market

EGARCH MODEL

\begin{tabular}{|c|c|c|c|c|c|c|c|c|c|}
\hline & \multicolumn{3}{|c|}{ KSE All Shares } & \multicolumn{3}{|l|}{ KSE-100 } & \multicolumn{3}{|l|}{ KSE-30 } \\
\hline & Coeff. & z-stat. & Prob. & Coeff. & z-stat. & Prob. & Coeff. & z-stat. & Prob. \\
\hline \multicolumn{10}{|l|}{ Mean Equation } \\
\hline C & 0.00062 & 18.50644 & 0 & $-1.76 \mathrm{E}-03$ & -12.57207 & 0 & 0.00078 & 3.648806 & 0.0003 \\
\hline First Day of Week & 0.000672 & 5.295632 & 0 & -0.010164 & $-1.53 E+02$ & 0 & -0.001657 & -4.769006 & 0 \\
\hline Last Day of Week & 0.006744 & 180.4589 & 0 & $1.02 \mathrm{E}-02$ & 58.00319 & 0 & 0.000734 & 1.717282 & 0.0859 \\
\hline $\operatorname{AR}(1)$ & 0.248713 & 17.33798 & 0 & 0.248919 & 17.35329 & 0 & 0.368898 & 22.45844 & 0 \\
\hline \multicolumn{10}{|c|}{ Variance Equation } \\
\hline C & -1.988581 & -307.9053 & 0 & -0.298003 & -30.37329 & 0 & -0.884272 & -14.89118 & 0 \\
\hline ARCH Term & 2.056258 & 264.7874 & 0 & 0.78191 & 60.61261 & 0 & 0.304709 & 14.33157 & 0 \\
\hline Asymmetry term & -0.63007 & -123.1655 & 0 & -0.504549 & -66.56286 & 0 & -0.129459 & -11.62033 & 0 \\
\hline GARCH & 0.899303 & 1094.434 & 0 & 1.019741 & 701.5497 & 0 & 0.927381 & 158.5309 & 0 \\
\hline
\end{tabular}

\section{ARCH LM Test}

\begin{tabular}{|c|c|c|c|c|c|c|c|c|}
\hline & & t-Statistic & Prob. & & t-Statistic & Prob. & t-Statistic & Prob. \\
\hline & & -0.200167 & 0.8414 & & 0.321225 & 0.7481 & -0.271088 & 0.7863 \\
\hline & \multicolumn{3}{|l|}{ KMI-30 } & \multicolumn{3}{|c|}{ KMI All Shares } & & \\
\hline & Coeff. & z-stat. & Prob. & Coeff. & z-stat. & Prob. & & \\
\hline \multicolumn{9}{|l|}{ Mean Equation } \\
\hline C & 0.001147 & 5.293387 & 0 & 0.000703 & 1.892587 & 0.0584 & & \\
\hline First Day of Week & -0.001554 & -4.383768 & 0 & -0.001377 & -2.314733 & 0.0206 & & \\
\hline Last Day of Week & 0.001034 & 2.383335 & 0.0172 & $3.86 \mathrm{E}-05$ & 0.05276 & 0.9579 & & \\
\hline $\mathrm{AR}(1)$ & 0.339424 & 18.6666 & 0 & 0.108162 & 3.284138 & 0.0011 & & \\
\hline \multicolumn{9}{|l|}{ Variance Equation } \\
\hline C & -0.803687 & -11.36327 & 0 & -0.710072 & -5.88148 & 0 & & \\
\hline ARCH Term & 0.248547 & 12.46143 & 0 & 0.159072 & 4.746941 & 0 & & \\
\hline Asymmetry term & -0.141531 & -11.83761 & 0 & -0.141562 & -6.595087 & 0 & & \\
\hline GARCH & 0.93286 & 137.4377 & 0 & 0.937997 & 80.45798 & 0 & & \\
\hline \multicolumn{9}{|l|}{ ARCH LM Test } \\
\hline & & t-Statistic & Prob. & & t-Statistic & Prob. & & \\
\hline & & 0.769549 & 0.4416 & & 0.084081 & 0.933 & & \\
\hline
\end{tabular}


Table 9: Model Selection Criteria

\begin{tabular}{llll}
\hline \multicolumn{2}{l}{ Summary of Model Selection } & & \\
Test & AIC & SIC & HQC \\
GARCH & 0 & 0 & 0 \\
TARCH & 4 & 4 & 4 \\
EGARCH* & 11 & 11 & 11 \\
\hline Total Models & 15 & 15 & 15 \\
\hline
\end{tabular}

*Criterions Suggested EGRACH Model Specification **Details are in Annexure 1

OLS, GARCH, TARCH, and EGARCH statistical tests were adopted to find out the best fit. Studies employed the EGARCH model based on $\mathrm{HIC}$, SIC, and HQC value, the least value of criterion the best is model. Above table illustrating that in 11 equations EGARCH model had the least criterion values, we had to employ a single test to keep uniformity in the study so the EGRACH model was employed in each indexed situational model. Model distribution in two categories could be difficult and would not have consistency so a single model was adopted and this is one of the limitations of this study.

Indexes took as KSE All Share, KSE-100 Index, KSE30, KMI-30, and KMI All Share indexes, and each index comprised on 449 (100\% Capitalization), 100 (82.74\%), 30 (40.83\%). 30 (31.31\%) and 227 (54.67\%) respectively, Estimated equations above illustrating shift of investment from equity to debt market, as equation is exhibiting that investor are more sensitive to interest rate and T-bill rates in KSE-ALL Index, most investor shift their investment from risky to risk free securities that is being cover by the estimated coefficient of T-bill rates, mover KSE-All is complete picture of stock exchange by covering whole outstanding tradable share in stock market, KSE-All share reports negative relationship with exchange rate, that further witnessed investor get discourage if there is rise in exchange rate and the feel insecure because of currency deficiency, as Pakistan has considerable number in export that frequently having noticeable contribution in Gross Domestic Product of Pakistan, meanwhile being relying on domestic and international trade nature so if there is currency depreciated than cost of production will increase and reflects in the balance sheet of firms in the head of Cost of Goods Sold because Pakistan is one of import oriented country and we heavily import machineries, essential inventories and key ingredients which are used for final production such, Pakistan's Stock market is being dominated by Manufacturing firms because of this import impact a lot so exchange rate plays pivotal role in stock indices, investor feels happy and encourage to invest in stock market if local currency appreciated, moreover it is further noticeable that Pakistan Stock Exchange is being ruled by few of biggest local players (Brokerage Houses) who inherent around $60 \%$ hold of entire market, meaning there is very steady foreign direct investment but heavy local investments. KSE-100 index return has no significant association with Interest Rate (Proxy KIBOR) and Treasury Bill Rates, but with the exchange rate dependent variable has a significant negative relationship that has been explaining above.

Table 10: Sensitivity Analysis

\begin{tabular}{|c|c|c|c|c|c|c|c|c|c|}
\hline \multicolumn{5}{|c|}{ KSE-ALL Share Index } & \multicolumn{5}{|c|}{ KSE-100 Index } \\
\hline Variable & Coefficient & Std. Error & t-Statistic & Prob. & Variable & Coefficient & Std. Error & t-Statistic & Prob. \\
\hline KIBOR & -0.27 & 0.14 & -1.97 & 0.05 & KIBOR & -0.0000265 & 0.0000859 & -0.308875 & 0.7577 \\
\hline D(TBILLS) & -0.67 & 0.33 & -2.03 & 0.04 & D(TBILLS) & -0.57733 & 0.348447 & -1.656867 & 0.0991 \\
\hline ER & -0.8 & 0.29 & -2.78 & 0.01 & ER & -0.891163 & 0.309143 & -2.882689 & 0.0044 \\
\hline $\mathrm{C}$ & 0.04 & 0.01 & 3.5 & 0 & $\mathrm{C}$ & 0.022562 & 0.005074 & 4.446475 & 0 \\
\hline $\begin{array}{l}\text { Adj. } \\
\text { R-squared }\end{array}$ & 0.082125 & $\begin{array}{l}\text { BPG Test } \\
\text { p-value }\end{array}$ & F-statistic & Prob. F & $\begin{array}{l}\text { Adj. } \\
\text { R-squared }\end{array}$ & 0.053949 & $\begin{array}{l}\text { BPG Test } \\
\text { p-value }\end{array}$ & F-statistic & Prob. F \\
\hline DW-stat & 1.928793 & 0.8293 & 6.471841 & 0.000325 & DW-stat & 1.79292 & 0.4468 & 3.915769 & 0.009516 \\
\hline \multicolumn{5}{|c|}{ KSE-30 Index } & \multicolumn{5}{|c|}{ KMI-30 Index } \\
\hline Variable & Coefficient & Std. Error & t-Statistic & Prob. & Variable & Coefficient & Std. Error & t-Statistic & Prob. \\
\hline KIBOR & -0.000231 & 0.000273 & -0.846685 & 0.3986 & KIBOR & -0.000334 & 0.000212 & -1.576834 & 0.1176 \\
\hline D(TBILLS) & -2.161463 & 1.509086 & -1.432299 & 0.1543 & $\mathrm{D}(\mathrm{TBILLS})$ & -0.471839 & 1.444749 & -0.326589 & 0.7446 \\
\hline ER & -0.973744 & 0.391394 & -2.487883 & 0.014 & ER & -0.717985 & 0.319589 & -2.246585 & 0.0266 \\
\hline C & 0.010281 & 0.006479 & 1.586797 & 0.1148 & $\mathrm{C}$ & 0.016904 & 0.004829 & 3.500465 & 0.0007 \\
\hline $\begin{array}{l}\text { Adj. } \\
\text { R-squared }\end{array}$ & 0.090951 & $\begin{array}{l}\text { BPG Test } \\
\text { p-value }\end{array}$ & F-statistic & Prob. F & $\begin{array}{l}\text { Adj. } \\
\text { R-squared }\end{array}$ & 0.095176 & $\begin{array}{l}\text { BPG Test } \\
\text { p-value }\end{array}$ & F-statistic & Prob. F \\
\hline DW-stat & 1.940146 & 0.7905 & 4.6357 & 0.004028 & DW-stat & 2.29365 & 0.3217 & 3.962041 & 0.009971 \\
\hline
\end{tabular}


Calendar Anomalies or illusions? Evidence from Pakistan Stock Market

\begin{tabular}{|c|c|c|c|c|c|}
\hline S.no & Sector & $\begin{array}{l}\text { No. of } \\
\text { Companies }\end{array}$ & Nature of Company & $\begin{array}{l}\text { Volume-based on } \\
\text { Market Value }\end{array}$ & $\begin{array}{l}\text { Market } \\
\text { Share }\end{array}$ \\
\hline 1 & COMMERCIAL BANKS & 20 & Non-Manufacturing & 1027381.321 & $18.17 \%$ \\
\hline 2 & OIL \& GAS EXPLORATION COMPANIES & 4 & Manufacturing & 726633.6507 & $12.85 \%$ \\
\hline 3 & FOOD \& PERSONAL CARE PRODUCTS & 20 & Manufacturing & 544018.7722 & $9.62 \%$ \\
\hline 4 & TOBACCO & 3 & Manufacturing & 530989.1023 & $9.39 \%$ \\
\hline 5 & FERTILIZER & 6 & Manufacturing & 419491.0453 & $7.42 \%$ \\
\hline 6 & CEMENT & 19 & Manufacturing & 318329.9635 & $5.63 \%$ \\
\hline 7 & CHEMICAL & 26 & Manufacturing & 268163.884 & $4.74 \%$ \\
\hline 8 & POWER GENERATION \& DISTRIBUTION & 14 & Manufacturing & 231104.6486 & $4.09 \%$ \\
\hline 9 & PHARMACEUTICALS & 12 & Manufacturing & 205534.3699 & $3.63 \%$ \\
\hline 10 & TEXTILE COMPOSITE & 36 & Manufacturing & 194943.99 & $3.45 \%$ \\
\hline 11 & AUTOMOBILE ASSEMBLER & 13 & Manufacturing & 194622.7008 & $3.44 \%$ \\
\hline 12 & OIL \& GAS MARKETING COMPANIES & 8 & Manufacturing & 143401.154 & $2.54 \%$ \\
\hline 13 & INSURANCE & 25 & Non-Manufacturing & 129437.4408 & $2.29 \%$ \\
\hline 14 & INV. BANKS / INV. COS. / SECURITIES COS. & 22 & Non-Manufacturing & 85318.56692 & $1.51 \%$ \\
\hline 15 & TECHNOLOGY \& COMMUNICATION & 12 & Manufacturing & 64221.93985 & $1.14 \%$ \\
\hline 16 & MISCELLANEOUS & 18 & Manufacturing & 62104.43191 & $1.10 \%$ \\
\hline 17 & SUGAR \& ALLIED INDUSTRIES & 27 & Manufacturing & 59326.0823 & $1.05 \%$ \\
\hline 18 & ENGINEERING & 17 & Manufacturing & 58448.95326 & $1.03 \%$ \\
\hline 19 & TRANSPORT & 5 & Non-Manufacturing & 58369.57664 & $1.03 \%$ \\
\hline 20 & REFINERY & 4 & Manufacturing & 45606.93915 & $0.81 \%$ \\
\hline 21 & PAPER \& BOARD & 8 & Manufacturing & 41137.03466 & $0.73 \%$ \\
\hline 22 & SYNTHETIC \& RAYON & 6 & Manufacturing & 39632.3379 & $0.70 \%$ \\
\hline 23 & AUTOMOBILE PARTS \& ACCESSORIES & 7 & Manufacturing & 39566.0122 & $0.70 \%$ \\
\hline 24 & TEXTILE SPINNING & 50 & Manufacturing & 38684.50292 & $0.68 \%$ \\
\hline 25 & GLASS \& CERAMICS & 8 & Manufacturing & 33619.12558 & $0.59 \%$ \\
\hline 26 & LEATHER \& TANNERIES & 4 & Manufacturing & 23307.21835 & $0.41 \%$ \\
\hline 27 & REAL ESTATE INVESTMENT TRUST & 1 & Manufacturing & 22815.162 & $0.40 \%$ \\
\hline 28 & CABLE \& ELECTRICAL GOODS & 7 & Manufacturing & 20670.50312 & $0.37 \%$ \\
\hline 29 & MODARABAS & 28 & Non-Manufacturing & 11369.94157 & $0.20 \%$ \\
\hline 30 & VANASPATI \& ALLIED INDUSTRIES & 3 & Manufacturing & 6280.210979 & $0.11 \%$ \\
\hline 31 & LEASING COMPANIES & 5 & Non-Manufacturing & 4015.45965 & $0.07 \%$ \\
\hline 32 & CLOSE - END MUTUAL FUND & 3 & Non-Manufacturing & 3293.15375 & $0.06 \%$ \\
\hline 33 & TEXTILE WEAVING & 7 & Manufacturing & 2508.482181 & $0.04 \%$ \\
\hline \multirow[t]{5}{*}{34} & WOOLLEN & 1 & Manufacturing & 368.3671875 & $0.01 \%$ \\
\hline & Total & 449 & & 5654716.045 & $100.00 \%$ \\
\hline & Summary & & & & \\
\hline & Non-Manufacturing & $23.33 \%$ & & & \\
\hline & Manufacturing & $76.67 \%$ & & & \\
\hline
\end{tabular}


The rest of the two indexes KSE-30 and KMI-30 possess $40.83 \%$ \& $31.31 \%$ market share respectively, further, these both indices are quite similar in the context of indexed companies, as below.

\begin{tabular}{lll|lll}
\hline KMI-30 & & & KSE-30 & & \\
\hline ATRL & MARI & SEARL & ATRL & MARI & SEARL \\
\hline DAWH & MEBL & SNGP & DGKC & MEBL & SNGP \\
\hline EFERT & MLCF & SSGC & EFERT & MLCF & \\
\hline ENGRO & MTL & UNITY & ENGRO & MTL & \\
\hline EPCL & NML & NETSOL & EPCL & NML & \\
\hline FCCL & OGDC & PSMC & FCCL & OGDC & \\
\hline HUBC & PAEL & KEL & HUBC & PAEL & \\
\hline ISL & POL & FCEPL & ISL & POL & \\
\hline LOTCHEM & PPL & HCAR & LOTCHEM & PPL & \\
\hline LUCK & PSO & DGKC & LUCK & PSO & \\
\hline
\end{tabular}

*22 Companies are same in KSE-30 and KMI-30 Index

Around $70 \%$ of companies are the same in both of the indices, these both indices have a significant and negative relationship with Exchange Rate but not significant with Interest Rate and Treasury Bills Rate. Therefore, it is concluded that investor is more sensitive in term of the exchange rate in each index but while considering entire market investors are even sensitive to interest rate and T-bill rate, $\mathrm{KMI}$ All shares returns has not been shown because estimated coefficient was insignificant which does not make any meaning in a sensitivity analysis. No autocorrelation has been detected in any of equation as well as no heteroscedasticity impact found in these equations. Collectively these all variables on average explaining indices around $8.06 \%$ and rest of unexplained proportion are $91.94 \%$ which may be explained by some other variable that has been taken in this research.

Correlogram illustrated that there is no serial correlation amongst the residuals of the estimated equation, in each column we have shown results of all 5 indices with 10 lags, null hypothesis speaks that there is no serial correlation amongst residual of the estimated equation, hence none of the equation above has a value less than 0.05 or $5 \%$ which mean that models were fit and had no serial correlation impact, but one of the limitations in this research that Jarque-Bera's $p$-value is less than 0.05 in each of the indices.

\section{Discussion \& Conclusions}

Stock Market Anomalies always a problematic for and individual Investor, Brokerage Firms, Investment Banks, and other Financial Institutions because that such ups and down movement in the stock market not only comprised on the single factor but there are multiple factors which have influential power to stock market returns such as Index own History (Clustering Effect), Leadership Style (Policy Makers), Macroeconomic situation of a certain country and investor behavioral while investing into the stock market, hence few of the factor were encountered in this piece of research such as Year Turn Effect, Month Turn Effect and Week Turn Effect. Stock indexes sensitivity was testified with robust macroeconomic indicators to find out the role of

Table 11: Diagnostic Test

\begin{tabular}{llllllll}
\hline \multicolumn{2}{l}{ Correlogram Squared Residuals } & & & & & \\
Lagged & Autocorrelation & Partial Correlation & KSE ALL & KSE-100 & KSE-30 & KMI-30 & KMI ALL \\
1 & No & No & 0.945 & 0.882 & 0.786 & 0.441 & 0.933 \\
2 & No & No & 0.994 & 0.989 & 0.956 & 0.733 & 0.882 \\
3 & No & No & 0.999 & 0.998 & 0.993 & 0.881 & 0.969 \\
4 & No & No & 1 & 1 & 0.989 & 0.933 & 0.859 \\
5 & No & No & 1 & 1 & 0.995 & 0.938 & 0.72 \\
6 & No & No & 1 & 1 & 0.997 & 0.973 & 0.787 \\
7 & No & No & 1 & 1 & 0.999 & 0.974 & 0.481 \\
8 & No & No & 1 & 1 & 1 & 0.987 & 0.58 \\
9 & No & No & 1 & 1 & 1 & 0.993 & 0.459 \\
10 & No & No & 1 & 1 & 1 & 0.994 & 0.502 \\
& & Jarque-Bera & 1690 & 1561 & 1217 & 1221 & 11.63 \\
& & p-value & 0.00 & 0.00 & 0.00 & 0.00 & 0.00 \\
\hline
\end{tabular}

*Indices value is the $p$-values driven from correlogram squared residual test **We have run equation on 36 lags, but results were the same. 
economics in term of stock market anomalies, means in each on the anatomy which somehow related with stock market indices return was encountered.

EGARCH equation emphasis that around $70 \%$ of the firms listed in the Pakistan Stock Exchange has closing year as of June and rest as December, September, March, and November, firms listed in PSX has positive market volatility in the closing year of an entity due to disclosure of financial statements and dividend encashment. Month Turn effect first and last week of the months was reported negative market anomalies in KSE All share and KSE-100 and in the rest it is positive but overall market exhibited the negative market retur$n s$ in the first and the last, first and last day of the market was incorporated to find out the market behavioral in these two days hence it has resulted that in the last day of the week market exhibited positive return and in the first day of the week illustrated negative return, further, these results are very consistent in each index from these 19 years therefore driven conclusion speaks out that investor discourages withdrawing money in the last day but encourage in the first day of the week.

\section{Recommendations:}

\section{Recommendation for an Individual Investor:}

To create a supernormal return by exploiting these market anomalies must consider clustering effect in the market not only clustering effect but also sovereign and country risk in Pakistan, further, this research suggests us that how the market moves in each of the segment by modelling data and incorporating the role of information investor can make sufficient profit further even study suggested that role of herding behavioral in the market as big-play moves an individual do not wait to shuffle investment move with big tycoons of the stock market.

\section{Recommendation for Financial Institutions:}

In this study not only we have highlighted the role of clustering feature but also the role of the compositi- on of portfolios, role of sectors and the role of business activities in Karachi, therefore financial institution also consider these rest of anatomies which may cause market anomalies, construct such strategies that may beat market returns and generate supernatural return such as Lakson Asset Allocation Developed Market, Atlas Stock Fund and MCB Pakistan Frequent Payout Fund, their strategies always beat market returns and in negative market returns these funds produce positive returns just because of their intellectual portfolio management, smart investment movement and the right time to enter and exit the market.

\section{Recommendation for Policy Makers:}

In the growth of any stock market around the globe there is a gigantic role of regulators, this study suggest that firstly there should be more sophisticated regulatory framework for brokerage houses, because due to heavy pool investment these brokers can set market trend easily in result an individual investor is destroyed, the second policies such like in dictatorship should be adopted such as considerable rate of interest, policies to govern import and export and overseeing top management of firms, therefore around $70 \%$ of the stock market consist on Manufacturing Companies and PSX is the reflection Pakistan's economy so make some valuable measure that may improve exchange rate so that manufacturing firm make the most of exchange rate and contribute in the GDP of Pakistan, and third the last not make virtual information forums from where investor can avail off site balance sheet information (Not Confidential by the Entities) because these forums can avoid rumours and as Pakistan Stock Market is very sensitive with such rumours such as due to global pandemic COVID-19 investor are very conscious about their investment securities and situation still unpredictable so these virtual forums can give much confidence to the investor and these forums play very important role to established market and avoid such uncertainty to revoke market crashed. 


\section{References}

Agrawal, A., Tandon, K. J. J. o. i. M., \& Finance. (1994). Anomalies or illusions? Evidence from stock markets in eighteen countries. 13(1), 83-106.

Ariel, R. A. J. J. o. f. e. (1987). A monthly effect in stock returns. 18(1), 161-174.

Assogbavi, T., Osagie, J. E. J. I. B., \& Journal, E. R. (2006). Equity valuation process and price-volume relationship on emerging stock markets. 5(9).

Athanassakos, G. J. J. o. I., Fall. (1997). Firm size, stock return seasonality, and the trading pattern of individual and institutional investors: The Canadian experience.

Booth, G. G., Kallunki, J.-P., Martikainen, T. J. J. o. I. F. M., Institutions, \& Money. (2001). Liquidity and the turn-of-themonth effect: evidence from Finland. 11(2), 137-146.

Branch, B. J. t. J. o. B. (1977). A tax loss trading rule. 50(2), 198-207.

Brooks, R. M., Kim, H. J. T. Q. R. o. E., \& Finance. (1997). The individual investor and the weekend effect: A reexamination with intraday data. 37(3), 725-737.

Cadsby, C. B., Ratner, M. J. J. o. B., \& Finance. (1992). Turn-ofmonth and pre-holiday effects on stock returns: Some international evidence. 16(3), 497-509.

Canova, F., Hansen, B. E. J. J. o. B., \& Statistics, E. (1995). Are seasonal patterns constant over time? A test for seasonal stability. 13(3), 237-252.

Chang, E. C., Pinegar, J. M., Ravichandran, R. J. J. o. F., \& Analysis, q. (1993). International evidence on the robustness of the day-of-the-week effect. 497-513.

Cross, F. J. F. a. j. (1973). The behavior of stock prices on Fridays and Mondays. 29(6), 67-69.

Dhankar, R. S. (2019). Capital Markets and Investment Decision Making: Springer.

Dimson, E., \& Marsh, P. J. T. J. o. P. M. (1999). Murphy's law and market anomalies. 25(2), 53-69.

Doyle, J. R., Chen, C. H. J. J. o. B., \& Finance. (2009). The wandering weekday effect in major stock markets. 33(8), 1388-1399.

French, K. R. J. J. o. f. e. (1980). Stock returns and the weekend effect. 8(1), 55-69.

Gibbons, M. R., \&Hess, P. J. J. o. b. (1981). Day of the week effects and asset returns. 579-596.

Hansen, P. R., Lunde, A., \& Nason, J. M. J. F. R. B. O. A. W. P. (2005). Testing the significance of calendar effects. (2005-02).

Harris, M., \& Raviv, A. J. T. R. o. F. S. (1993). Differences of opinion make a horse race. 6(3), 473-506.

Hong, H., \& Stein, J. C. J. J. o. E. p. (2007). Disagreement and the stock market. 21(2), 109-128.
Hui, T.-K. J. O. (2005). Day-of-the-week effects in US and AsiaPacific stock markets during the Asian financial crisis: a non-parametric approach. 33(3), 277-282.

Jaffe, J., \&Westerfield, R. J.T. j. o. f. (1985). The week-end effect in common stock returns: The international evidence. $40(2)$, 433-454.

Johnston, K., Cox, D. R. J. Q. J. o. B., \& Economics. (1996). The influence of tax-loss selling by individual investors in explaining the January effect. 14-20.

Karpoff, J. M. J. J. o. F., \& Analysis, q. (1987). The relation between price changes and trading volume: A survey. 109-126.

Kohers, G., Kohers, N., Pandey, V., \& Kohers, T. J. A. E. L. (2004). The disappearing day-of-the-week effect in the world's largest equity markets. 11(3), 167-171.

Kunkel, R. A., Compton, W. S., \& Beyer, S. J. I. R. o. F. A. (2003). The turn-of-the-month effect still lives: the international evidence. 12(2), 207-221.

Lee, I. J. J. o. B. F., \& Accounting. (1992). Stock market seasonality: Some evidence from the Pacific-Basin countries. 19(2), 199-210.

Lee, K.-Y., Chang, C.-S. J. Q. J. o. B., \& Economics. (1988). Anomalies in the stock returns over trading and nontrading periods: Further evidence in the Korean stock market. 139-161.

Martikainen, T., Perttunen, J., \& Puttonen, V. J. J. o. F. M. (1995). Finnish turn-of-the-month effects: Returns, volume, and implied volatiliy. 15(6), 605-615.

Nikkinen, J., Sahlström, P., Takko, K., Äijö, J. J. I. J. o. E., \& Finance. (2009). Turn-of-the-month and intramonth anomalies and US macroeconomic news announcements on the thinly traded Finnish Stock Market. 1(2), 3-11.

Ogden, J. P. J. T. J. o. F. (1990). Turn-of-month evaluations of liquid profits and stock returns: A common explanation for the monthly and January effects. 45(4), 1259-1272.

Pettengill, G. N. J. Q. J. o. B., \& Economics. (2003). A survey of the Monday effect literature. 42(3/4), 3-27.

Rogalski, R. J. J. T. J. o. F. (1984). New findings regarding day-ofthe-week returns over trading and non-trading periods: a note.39(5), 1603-1614.

Rosenberg, M. J. T. A. E. (2004). The monthly effect in stock returns and conditional heteroscedasticity. 48(2), 67-73.

Schwert, G. W. J. H. o. t. E. o. F. (2003). Anomalies and market efficiency. 1, 939-974.

Sullivan, R., Timmermann, A., \& White, H. J. J. o. E. (2001). Dangers of data mining: The case of calendar effects in stock returns. 105(1), 249-286. 